\title{
The Central Role of Home Prices in the Current Financial Crisis: How Will the Market Clear?
}

\begin{abstract}
This paper begins by describing some patterns in home price movements over recent decades. It then discusses some distinguishing characteristics of housing markets that will contribute to determining prices going forward: Housing is heterogeneous, making prices hard to measure. Home prices are subject to inertia and are sticky downward. Housing markets have traditionally been quantity clearing markets, with excess inventories absorbed only as new households are formed. And housing markets depend critically on credit market conditions and monetary policy. Two opposite scenarios for future home prices are both plausible: The first, noting among other things the many "underwater" mortgages and unsold inventories and the likelihood of a severe recession, foresees a slow recovery. The second observes that the market clearing process has been orderly so far and that deep regional housing busts in the past have sometimes been followed by quick recoveries, suggesting that a more rapid turnaround is possible.
\end{abstract}

he housing market today lies at the heart of a potentially catastrophic
collapse of the banking and financial system. By some measures, housing prices are down by more than even the most pessimistic forecasters were predicting a year ago. The collapse in value of the collateral behind the nation's $\$ 12$ trillion portfolio of home mortgages has led to unprecedented rates of delinquency and foreclosure. The decline in home prices has also led investors to unwind the layers of risk created by and traded in new, complex contracts, which now threaten the foundation of the payment system.

This paper begins with an overview of changes in the value of residential capital and land over the last four decades. It then lays out some salient facts about how the housing market has operated in the past, with a focus on 
alternative market clearing mechanisms. Finally, while stopping short of a specific forecast, the paper presents both the case for a continuing severe decline, with prices falling well into 2010, and an argument that the market may begin to stabilize as early as 2009Q1.

\section{Home Prices and Land Values in the United States, 1975-2007}

One national index of home prices suggests that nominal prices never fell over any full quarter between 1975 and 2005. The national quarterly repeat sales index of the Office of Federal Housing Enterprise Oversight (OFHEO; top panel of figure 1) rose 532.4 percent, or more than sixfold, in nominal terms between 1975Q1 and 2007Q1. The bottom panel of figure 1 plots the S\&P/Case-Shiller National Index, available back to 1987. Nominal home prices by this measure fell in a number of quarters, but the overall pattern is the same: prices were either rising or flat between 1987 and 2005. Nominal prices rose at an average annual rate of 6.0 percent over the whole period but began accelerating rapidly in 2000 .

Table 1 compares increases in home prices with income growth and inflation. Between January 1975 and December 2006, the consumer price index (CPI) rose nearly fourfold, implying an average annual rate of increase of about 4.3 percent over the 32 years. Personal income per capita grew at the same rate as home prices, although median household income did not keep pace.

Figure 2, which shows the OFHEO index in real terms, reveals four time periods when real home prices fell. For purposes of understanding behavior in the housing and mortgage markets, this paper will focus mostly on nominal home price changes, since household debt is carried in nominal terms.

Although national-average nominal home prices rarely or never fell during 1975-2005, boom-bust cycles led to substantial periods of decline in a number of regions. Table 2 presents a rough chronology of these ups and downs based on repeat sales indexes produced by Fiserv CSW and OFHEO. Between 1975 and the late 1990s, major price booms occurred in California (twice) and in the Northeast. Major busts occurred in Texas, the Northeast, and California.

In 1975 the national economy was in recession. During the recovery, California experienced a substantial housing price boom, with nominal prices rising 138 percent between 1975 and 1980. During the same period home prices in the rest of the country rose by only 64 percent. The California boom ended during the deep double-dip recession of 1980-83. With the fixed-rate 30 -year mortgage reaching 18 percent and the federal funds 
Figure 1. National Nominal Home Price Indexes, Quarterly Data
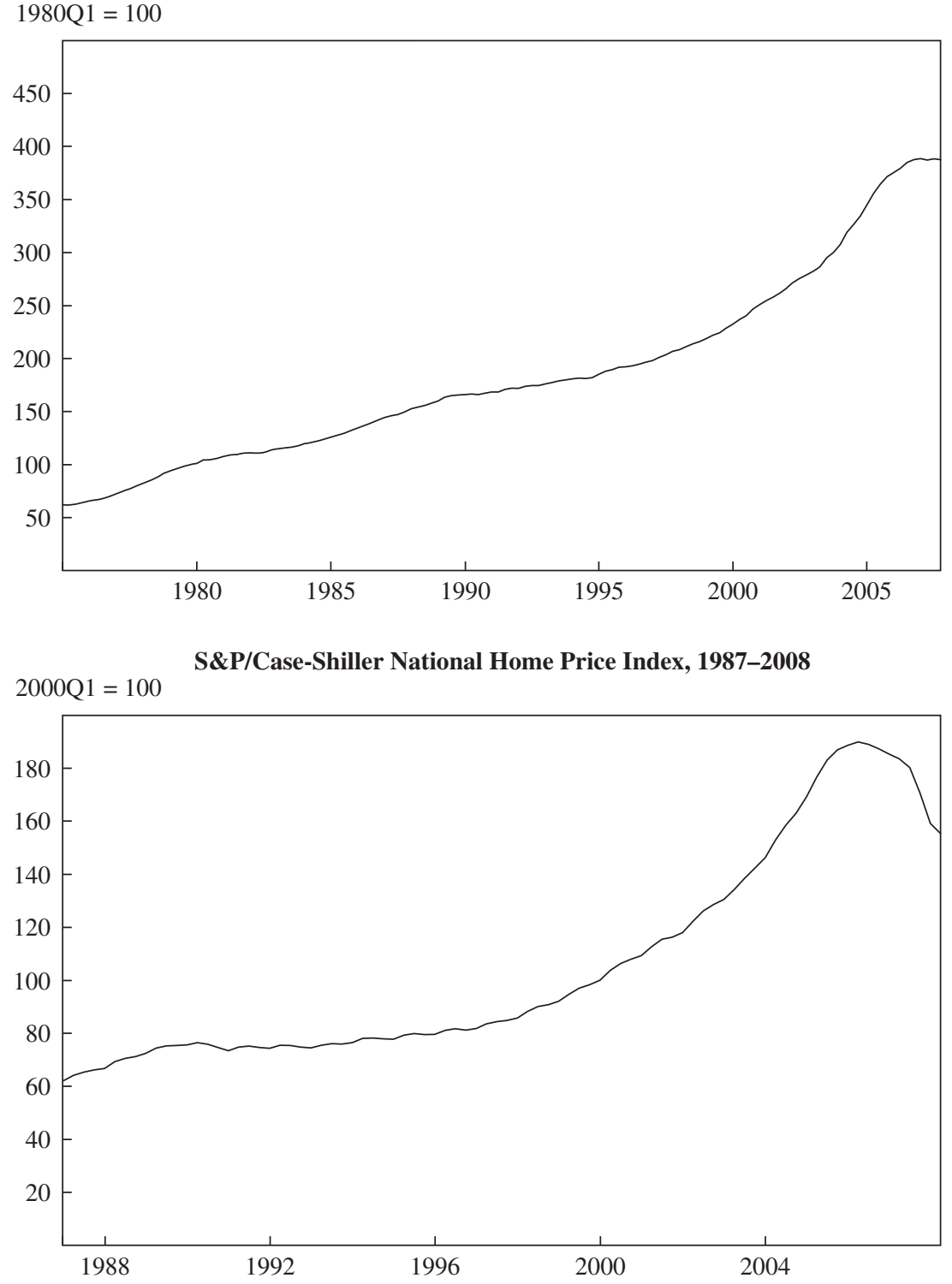

Sources: Office of Federal Housing Enterprise Oversight; Standard \& Poor's. 
Table 1. Changes in Home Prices, Income, and Consumer Prices, January 1975December 2006

Percent

\begin{tabular}{lcc}
\hline Indicator & $\begin{array}{c}\text { Total } \\
\text { change }\end{array}$ & $\begin{array}{c}\text { Annual } \\
\text { average }\end{array}$ \\
\hline OFHEO basic index of house prices & 528 & 5.9 \\
Median household income & 308 & 4.5 \\
Personal income per capita & 526 & 5.9 \\
Average hourly earnings & 270 & 4.2 \\
Consumer price index for all urban consumers (CPI-U) & 289 & 4.3
\end{tabular}

Sources: Office of Federal Housing Enterprise Oversight, Bureau of Economic Analysis, Bureau of Labor Statistics, and Moody's Economy.com.

rate peaking at 20 percent, demand dropped sharply, and many observers expected a sharp drop in home prices. Instead prices merely went flat from 1981 to late 1984, when the next boom began.

Between 1980 and 1985 the recession ended, inflation subsided, and interest rates fell. By the end of the period, national nominal home prices were up 24 percent, but prices remained substantially below their 1980 peaks in real terms.

Figure 2. Real Price of a Home Worth $\$ 100,000$ in 2000, 1975-2007

Thousands of dollars

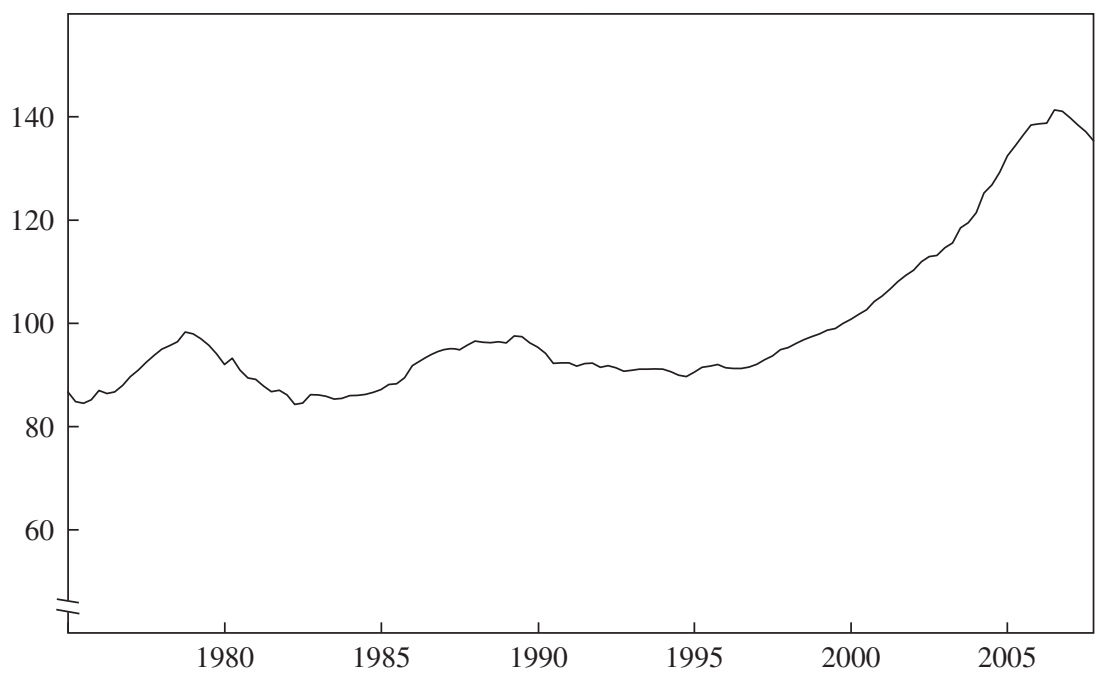

Sources: Office of Federal Housing Enterprise Oversight; author's calculations.

a. Values are calculated from the OFHEO National House Price Index adjusted for inflation using the consumer price index (CPI-U). 
Table 2. Housing Booms and Busts since 1975

Period and episode

1975-80

First California boom, ending in recession

U.S. national index

1980-85

Nominal prices in California hold

Deep recession followed by recovery

U.S. national index

1985-90

Texas bust (not preceded by boom), 1986-88

Bottom reached after 10 quarters

Oklahoma bust, 1983-88

Bottom reached after 19 quarters

New England-New York boom, 1984-88

$+110^{\mathrm{a}}$

New England-New York bust, 1988-92

Bottom reached after 14 quarters

Second California boom, 1984-90

$+92$

U.S. national index

1990-95

Second California bust

Bottom reached after 19 quarters

San Diego bust, 1990-96

Bottom reached after 24 quarters

U.S. national index

1995-2000

Housing prices rising nationwide

U.S. national index

2000-06

U.S. national index

Case-Shiller Composite 10

$+126$

Case-Shiller Composite 20

$+107$

Miami boom

$+181$

Bottom tier

$+241$

Los Angeles boom

$+174$

Bottom tier

$+240$

Washington, D.C., boom

$+151$

Bottom tier

$+197$

San Diego boom

$+150$

Bottom tier

$+197$

Las Vegas boom

$+135$

Bottom tier

$+144$

Phoenix boom

$+127$

Bottom tier

$+139$

Sources: Standard \& Poor's and Office of Federal Housing Enterprise Oversight.

a. Figure is for Boston only. 
From 1985 to 1990 the housing market took front and center. First, the oil patch states, which had never experienced a housing boom, saw a sharp decline in their economies, which felt the sting of oil prices falling to $\$ 10 \mathrm{a}$ barrel and newly aggressive bank examiners. ${ }^{1}$ Texas and the West South Central region saw home prices fall 14 percent in nominal terms, with a bottom after 10 quarters. A worse decline was felt in Oklahoma, where nominal prices fell 23 percent, and a bottom was not reached for 19 quarters. The impact on mortgage defaults was huge.

Precisely as Texas and the rest of the oil patch were in a bust, the Northeast and California housing markets were booming. Nominal home prices nearly doubled in the Northeast in the five years from 1984 to 1989. A second California boom, which also nearly doubled prices, was in full swing as the Northeast bubble burst in 1989.

Both the Northeast boom and the second California boom led to busts of significant magnitude. Nominal prices fell 12 percent in the Northeast, where a bottom was reached in 14 quarters. In California nominal prices fell 13 percent after their peak in 1990, and a bottom was not reached for 19 quarters. As in California a decade earlier, some areas did worse: in San Diego prices fell 17 percent and did not hit bottom for 24 quarters.

What came to be called the "rolling recession," with overlapping housing market cycles, kept national home price indexes rising steadily, with only modest cyclicality overall. There were no national booms or busts until 2000. Beginning in that year, regional housing markets suddenly began to move together. Over the next six years, a rapid acceleration occurred simultaneously in many regions, states, and metropolitan areas. Prices nationwide increased nearly 90 percent from 2000Q1 to 2006. The S\&P/Case-Shiller Composite 10 and Composite 20 indexes both more than doubled. ${ }^{2}$

The last panel of table 2 shows how strong the boom was in many areas. The gold medal goes to Miami, where prices increased 181 percent between 2000 and 2006. Los Angeles was just behind at 174 percent, with Washington, D.C., and San Diego both recording increases of 150 percent. The sharpest increases in each market were observed in the lowest tier by value. In Miami and Los Angeles the average property in the bottom tier more than tripled. Just behind them were the bottom tiers of San Diego and Washington.

1. See Congressional Budget Office (1991).

2. The Composite 10 index is an index of home prices in Boston, Chicago, Denver, Las Vegas, Los Angeles, Miami, New York, San Diego, San Francisco, and Washington, D.C. The Composite 20 includes, in addition, Atlanta, Charlotte, Cleveland, Dallas, Detroit, Minneapolis, Phoenix, Portland, Ore., Seattle, and Tampa. 
Table 3. Changes in Home Prices by Metropolitan Area through August 2008 Percent

\begin{tabular}{|c|c|c|c|c|c|c|}
\hline \multirow[b]{2}{*}{ Metropolitan area ${ }^{\mathrm{a}}$} & \multirow[b]{2}{*}{ Peak } & \multicolumn{5}{|c|}{ Change } \\
\hline & & $\begin{array}{l}\text { Since } \\
\text { peak }\end{array}$ & $\begin{array}{c}\text { Since } \\
\text { one year } \\
\text { before }\end{array}$ & $\begin{array}{c}\text { July to } \\
\text { August } \\
2008\end{array}$ & $\begin{array}{c}\text { June to } \\
\text { July } \\
2008\end{array}$ & $\begin{array}{c}\text { January } \\
2000 \text { to } \\
\text { August } \\
2008\end{array}$ \\
\hline Atlanta & Aug. 2006 & -7.7 & -8.5 & -0.2 & +0.3 & +24.8 \\
\hline Boston & Sept. 2005 & -10.8 & -4.7 & +0.1 & +0.2 & +62.8 \\
\hline Charlotte & Aug. 2007 & -2.8 & -2.8 & -0.8 & -0.2 & +32.1 \\
\hline Chicago & Sept. 2006 & -11.3 & -9.8 & 0.0 & -0.4 & +49.5 \\
\hline Cleveland & July 2006 & -10.5 & -6.6 & +1.1 & -0.3 & +10.5 \\
\hline Dallas & June 2007 & -2.8 & -2.7 & -0.2 & +0.6 & +22.9 \\
\hline Denver & Aug. 2006 & -5.4 & -5.1 & 0.0 & +0.8 & +32.6 \\
\hline Detroit & Dec. 2005 & -27.2 & -17.2 & 0.8 & +0.6 & -7.6 \\
\hline Las Vegas & Aug. 2006 & -35.9 & -30.6 & -2.4 & -2.8 & +50.5 \\
\hline Los Angeles & Sept. 2006 & -30.9 & -26.7 & -1.8 & -1.6 & +89.2 \\
\hline Miami & Dec. 2006 & -34.7 & -28.1 & -1.8 & -1.6 & +83.5 \\
\hline Minneapolis & Sept. 2006 & -17.1 & -13.8 & -1.0 & +1.3 & +41.9 \\
\hline New York & June 2006 & -10.7 & -6.9 & -0.2 & -0.7 & +92.8 \\
\hline Phoenix & June 2006 & -36.3 & -30.7 & -2.9 & -2.7 & +44.8 \\
\hline Portland, Ore. & July 2007 & -7.8 & -7.6 & -1.3 & -0.5 & +71.9 \\
\hline San Diego & Nov. 2005 & -32.8 & -25.8 & -2.3 & -1.8 & +68.2 \\
\hline San Francisco & May 2006 & -30.7 & -27.3 & -3.5 & -1.8 & +51.4 \\
\hline Seattle & July 2007 & -8.9 & -8.8 & -0.7 & -1.0 & +75.2 \\
\hline Tampa & July 2006 & -26.8 & -18.1 & -0.4 & 0.0 & +74.3 \\
\hline Washington, D.C. & May 2006 & -22.4 & -15.4 & -0.3 & -1.1 & +94.9 \\
\hline Composite 10 & June 2006 & -22.0 & -17.7 & -1.1 & -1.1 & +76.6 \\
\hline Composite 20 & July 2006 & -20.3 & -16.6 & -1.0 & -0.9 & +64.6 \\
\hline
\end{tabular}

Source: Standard \& Poor's, October 28, 2008.

a. Metropolitan areas are those tracked in the Case-Shiller Composite 20 index.

Not every city was as volatile on the upside. Atlanta, Charlotte, Cleveland, Dallas, Denver, and Detroit all saw healthy but unspectacular price growth ranging from 23 percent (Cleveland) to 40 percent (Denver). There was no hint of the kind of booms going on elsewhere.

Table 3 reports the most recent home price data as of this writing, released by Standard \& Poor's on October 28, 2008, and covering the period through August. The new data show the declines since the peak of the market, which occurred at different times in different cities. In September 2005 Boston became the first market to peak, and by March 2008, prices there had fallen 13.1 percent. Prices in Boston have increased slightly each month since April, so that by August the total decline had moderated to 10.8 percent. From the peak through June 2008, prices in Boston had fallen 
for 11 quarters. The pattern thus resembles the bust that occurred there from 1988 to 1992, when prices fell for 14 quarters. Prices in New York show a similar pattern.

The most severe declines have occurred in Las Vegas, Miami, and Phoenix, which have all seen prices drop by about 35 percent from peaks in mid- to late 2006 to August 2008. Just behind them comes California, where Los Angeles, San Diego, and San Francisco are down more than 30 percent from peak. Next, with declines of over 20 percent, are Detroit, Tampa, and Washington, D.C. Minneapolis is down 17 percent, followed by Boston, Chicago, Cleveland, and New York, with declines of just over 10 percent.

Between 2005 and 2008, for the first time since regional data became available, U.S. housing prices fell virtually everywhere. The S\&P/CaseShiller National Index was down 18.2 percent through 2008Q2, and the Composite 10 and Composite 20 indexes were down 22.0 percent and 20.3 percent, respectively, through August.

\section{Housing Prices and Income over the Cycle}

How did home prices fluctuate relative to local income over these cycles? In our 2003 Brookings Paper, Robert Shiller and I used state data to explore the relationship between changes in home prices and one measure of income. ${ }^{3}$ Using data including all 50 states and the District of Columbia from 1985 though 2002, we found a relatively stable relationship between personal income per capita and price in 43 states. In the remaining 8 , this relationship was cyclical and volatile.

Similar plots for the three decades leading up to 2008, however, show volatility spreading. In 2008 all metropolitan-area housing markets fell into one of three regimes: flat markets, single-peak markets, and regular-cycle markets. The flat market category includes most of the country. Figures 3 and 4 show the typical pattern of these markets for five metropolitan areas: Dallas, Memphis, and Pittsburgh, and Charlotte and Chicago. In these cities home prices did not significantly outpace income; indeed, they fell relative to income in most periods. In all cities but Chicago, the ratio of home prices to income per capita drops in the early 1980s and stays flat through 2007, between 3 and 5. In Chicago the ratio stays flat between 5 and 6 , rising to 7 after 2000 .

3. Case and Shiller (2003). 
Figure 3. Ratios of Home Prices to Personal Income per Capita in the Dallas, Memphis, and Pittsburgh Metropolitan Areas, 1976-2007a

Ratio

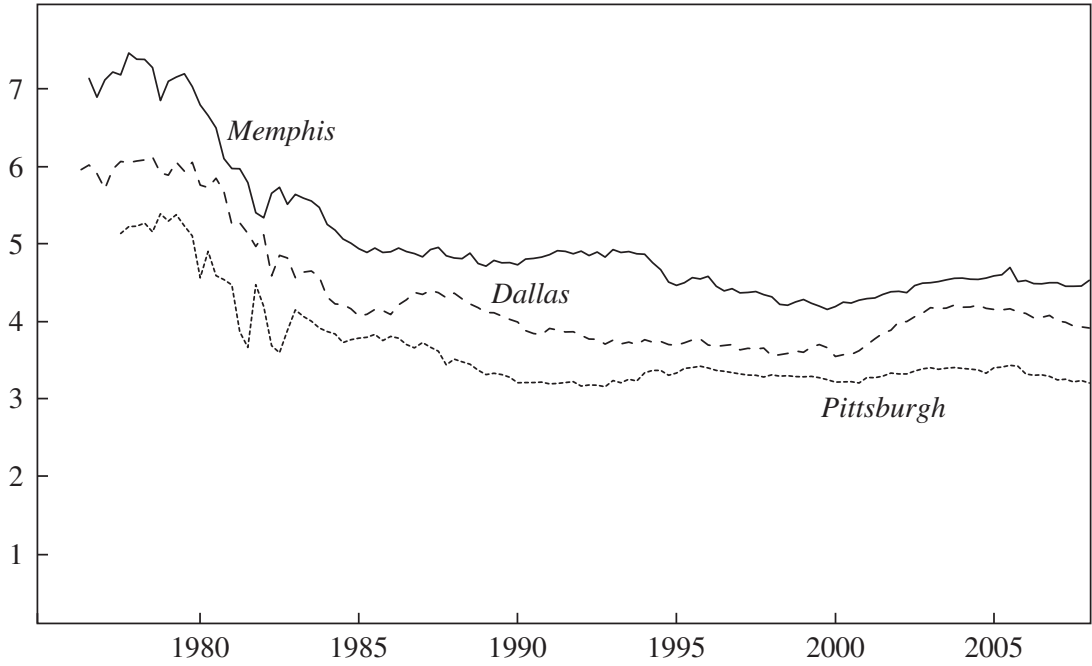

Sources: Office of Federal Housing Enterprise Oversight; author's calculations.

a. Median sales price of existing single-family houses in 2000 deflated with the OFHEO purchase-only price index for the indicated metropolitan area.

Figure 4. Ratios of Home Prices to Personal Income per Capita in the Chicago and Charlotte Metropolitan Areas, 1987-2008

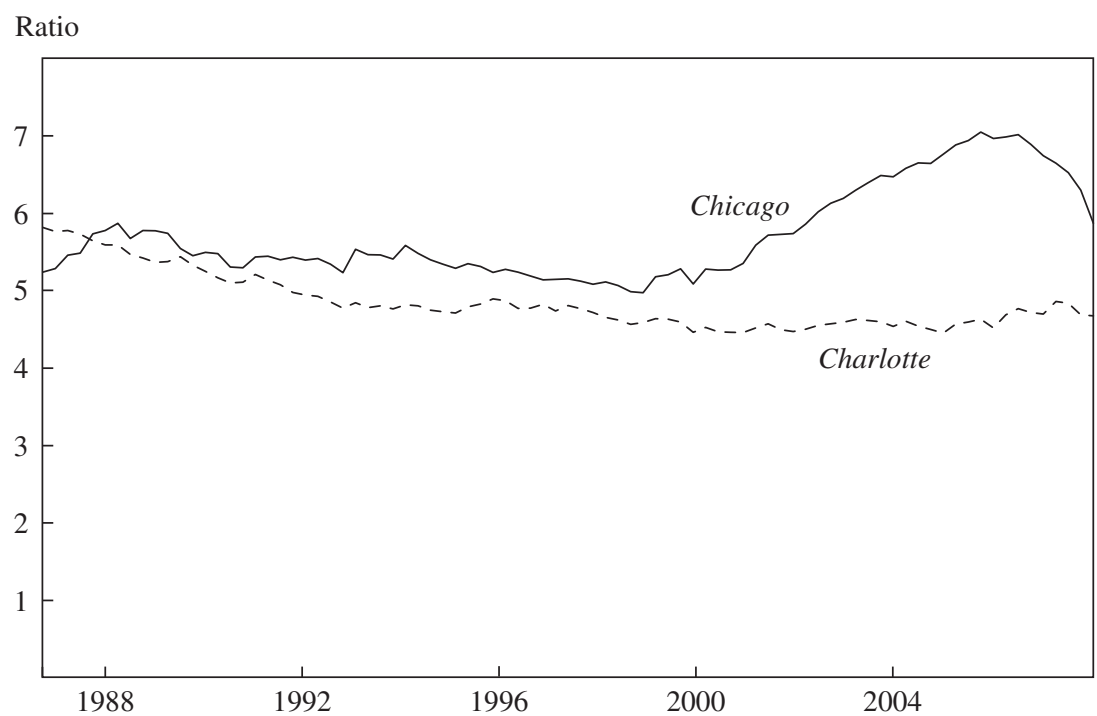

Sources: Standard \& Poor's; U.S. Census Bureau; Bureau of Economic Analysis; Moody's Economy.com. 
Figure 5. Ratio of Home Prices to Personal Income per Capita in the Phoenix and Miami Metropolitan Areas, 1989-2008

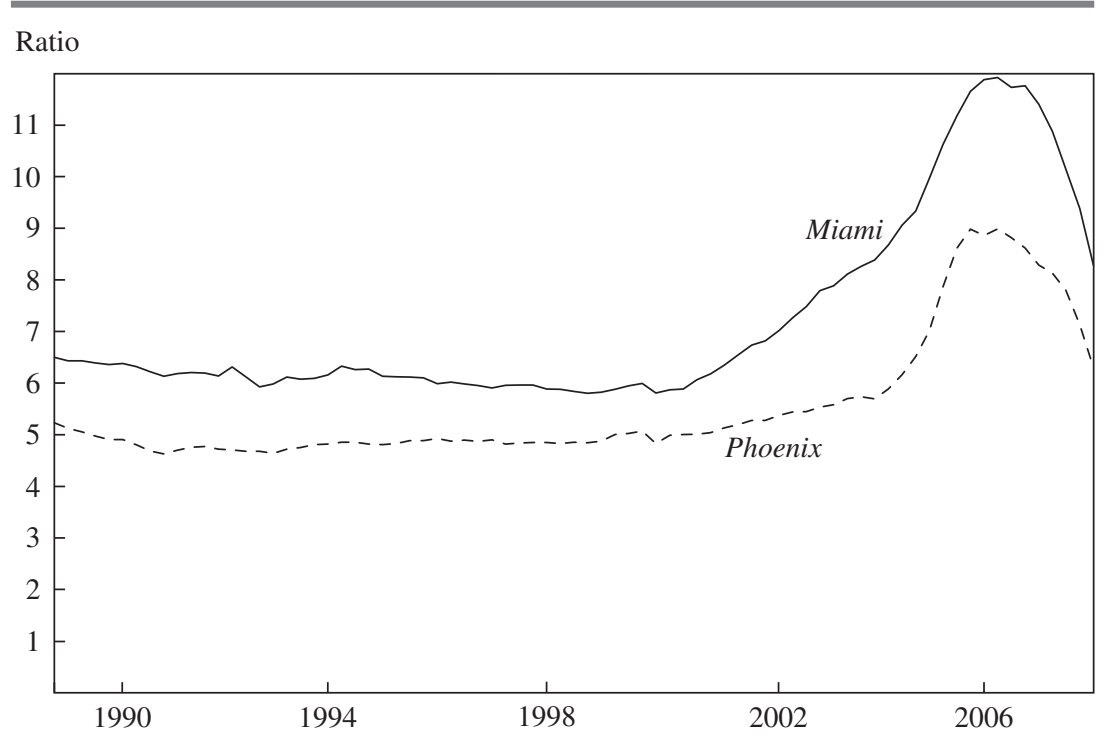

Sources: Standard \& Poor's; U.S. Census Bureau; Bureau of Economic Analysis; Moody’s Economy.com.

The single-peak markets are Las Vegas, Miami, and Phoenix. Figure 5 shows a remarkably similar pattern for the last two. The Phoenix market remained perfectly stable at a home price-income ratio of around 5 from 1989 through 2000. The ratio then rose slowly to 6 in 2004 before jumping up to 9 in 2006 and falling rapidly back to 6 in 2008. Miami's ratio was completely flat at about 6 until around 2000; it then accelerated upward to 12 by 2006 before dropping sharply.

In the regular-cycle markets of the Northeast and California, the boombust cycle has been virtually continuous. The ratio of home prices to income in Boston rose from 7 to over 11 during the boom that ended in 1988 (figure 6). This was followed by a drop back to just above 7 by the mid-1990s. Beginning in 1989 the ratio again rose sharply, peaking at 12 at the end of 2005. By the end of 2008Q1 it was back down to 10. A similar pattern can be found in data for the entire New York-New England region.

In Los Angeles the pattern is the same, but the ratios are higher. Starting at 7 in the mid-1980s, the ratio rose to almost 11 by 1990 before beginning a seven-year decline back to 6 by 1997. From 1997 to 2001 the ratio rose slowly and then accelerated, reaching 16 by the peak in 2006 before falling back to 11 by mid-2008. 
Figure 6. Ratio of Home Prices to Personal Income per Capita in the Boston and Los Angeles Metropolitan Areas, 1987-2008

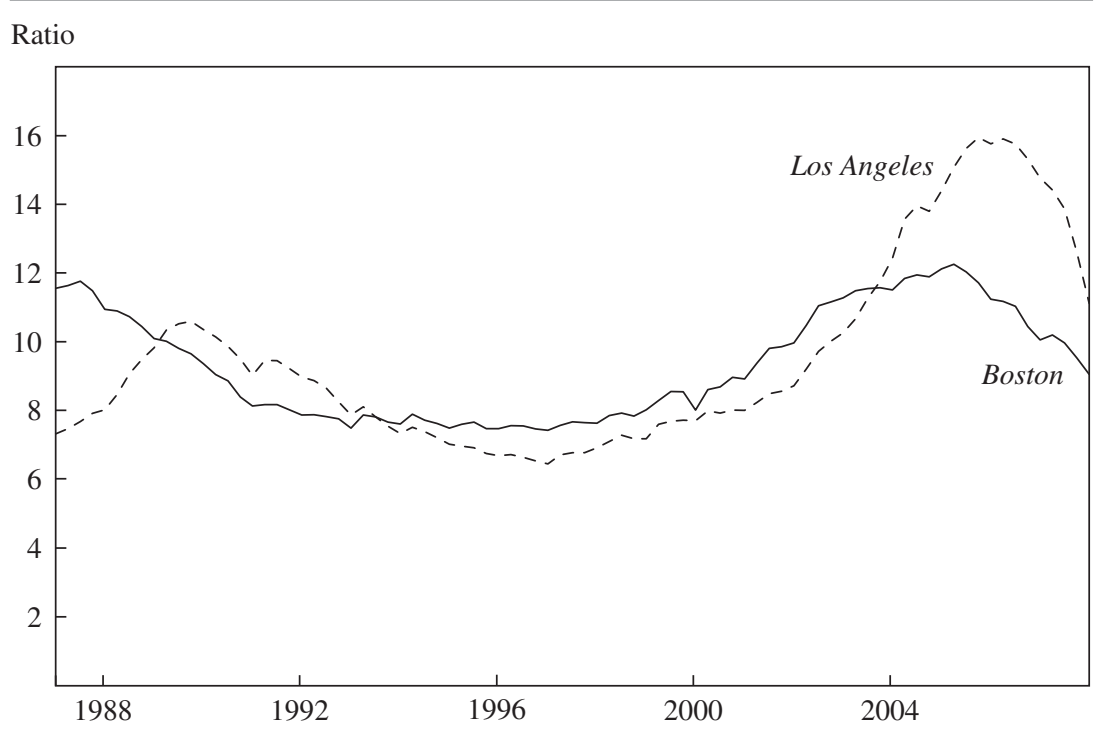

Sources: Standard \& Poor's; U.S. Census Bureau; Bureau of Economic Analysis; Moody's Economy.com.

\section{How Does the Housing Market Find a Bottom?}

Thus far this paper has simply described the pattern of home price movement over the past few decades. The questions of interest today are, When will prices stop falling? And when will order be restored to the battered housing and mortgage markets? If prices continue to fall into 2010, as many have argued they will, the books of mortgage business written in 2008 to 2009 are not likely to be profitable. If prices stop falling today, default rates will moderate, and recovery will soon follow.

This section of the paper describes the ways in which the housing market differs from other markets. These differences raise some issues that are integral to the process that will determine home values going forward. Some of the distinguishing characteristics of the housing market are the following:

- Housing is heterogeneous and prices are hard to measure.

- Prices are subject to inertia (bubbles) and are sticky downward.

- Housing markets have traditionally been quantity clearing markets.

- Housing markets depend critically on credit markets and monetary policy. 


\section{Housing Is Heterogeneous and Prices Are Hard to Measure}

The concept of a market price in the housing market is slippery, because every home is at least slightly different from every other. An individual home is a unique combination of both structural and neighborhood characteristics. The purchase of a home involves buying a bundle of attributes: living space, heating and other systems, usually a parcel of land of some dimension, a view, a number of rooms, various structural features (fireplaces, windows, appliances, and so on), and others. It also involves buying into a specific location with a specific natural environment, a school system, other amenities, a set of neighbors, a crime rate, and a tax rate. The purchased home may be of good or poor construction quality and (unless purchased new) may have been well or poorly maintained. Homes also differ in their degree of accessibility. All this makes it very difficult to look at a property, compare it with other properties, and know what it is worth.

The price of a home also includes the cost of the capital used to purchase it. Thinking about a home in this way highlights what makes it a potentially desirable investment. Consider a household buying a home outright, with no mortgage finance. The baseline yield on that investment (essentially the dividend) is the flow of housing services the household receives net of depreciation, maintenance, and taxes. The flow of dividends from an investment in corporate equity depends on profits and is taxable (albeit at a low rate). The flow of real net imputed rent, in contrast, is fixed and not taxable, and the costs of finance and property taxes are deductible. Thus, this component of yield has a stabilizing effect in downturns. Housing can therefore be seen as a substitute for equities in periods of uncertainty. In addition to the real services yield, there is the potential for capital gain, which for most households is also tax free. Housing is typically highly leveraged, however, so returns are volatile.

Forming reasonable expectations about gains is difficult, again because housing is heterogeneous. Much has been learned about how expectations are formed from extensive surveys of homebuyers in the Boston, Los Angeles, Milwaukee, and San Francisco metropolitan areas. These surveys were first conducted in 1988 and are now conducted annually. ${ }^{4}$ They illustrate several points: that expectations are backward looking, that buyers perceive little risk in purchasing a home, and that the expected returns are unrealistic. For example, two-thirds of buyers surveyed as recently as the spring of 2008 in Boston and San Francisco believed that prices would rise, not fall, that year. That figure was 75 percent in Milwaukee and 54 percent

4. For examples see Case and Shiller (1988, 2003); Case (2009). 
in Orange County, California. In the 2004 survey, 92 percent of respondents in Boston anticipated a one-year price rise, compared with over 95 percent in the other three sample sites. In the 2008 survey an even larger majority expected gains over 10 years, and the mean anticipated gain in three of the four cities was 10 percent a year $(7.5$ percent in again relatively pessimistic Boston).

At a minimum, measurements of changes in home prices must account for changes in physical attributes. There are two basic approaches, which both rely on arm's-length transactions: hedonic price indexes with time dummies, which require fine detail on changes in characteristics, and repeat sales indexes, which control for differences by looking only at properties with at least two observable sales during the relevant period. The advantages and disadvantages of these two approaches and the variations on them are the subject of much debate, which is beyond the scope of this paper. The important question, addressed below, is, How should these indexes be interpreted? What do they tell us about what is happening when they emerge from different market clearing processes taking place at the same time and in the same market?

\section{Home Prices are Subject to Inertia (Bubbles) and Are Normally Sticky Downward}

\section{In 1957 Paul Samuelson wrote,}

I have long been struck by the fact, and puzzled by it too, that in all the arsenal of economic theory we have absolutely no way of predicting how long [a bubble] will last. To say that prices will fall back to earth after they reach ridiculous heights represents a safe but empty prediction. Why do some manias end when prices have been ridiculous by 10 per cent, while others persist until they are ridiculous to the tune of hundreds of per cent? ${ }^{5}$

A good deal of evidence indicates that the housing market is prone to bubbles. I argued in 1986 that the price boom in Boston that began in 1984 was not caused by fundamentals but was indeed a bubble. ${ }^{6}$ A structural supply-and-demand model that had been reasonably successful at predicting home prices in 9 of the 11 cities in my sample suggested that fundamentals (income growth, interest rates, employment growth, demographics, and so forth) should have pushed Boston home prices up by 16 percent. Instead they increased by over 140 percent before peaking in late 1988 .

5. Samuelson (1957, p. 216).

6. Case (1986). 
Shiller and I constructed an accurate measure of price changes with transactions data obtained from Atlanta, Chicago, Dallas, and San Francisco. ${ }^{7}$ We found evidence of substantial positive serial correlation in real home prices. Our 1989 paper showed that a change in price observed over one year tends to be followed by a change in the same direction the following year between 25 and 50 percent as large. We found evidence of serial correlation in excess returns as well. Subsequent work demonstrated that both California and Massachusetts experienced price bubbles in the 1980s and 1990s. ${ }^{8}$

Price booms like those observed over the past 30 years are more likely to occur where the elasticity of supply of land is low, as in California and Massachusetts. The work of Edward Glaeser and his colleagues has focused attention on zoning and land use regulation. ${ }^{9}$ Markets with an elastic supply of developable land seemed to avoid price booms, Florida and Arizona being classic examples. From 1990 until 2000, home prices in these markets could be fully explained by income growth. Between 2000 and the first half of 2006, however, speculative demand boomed, driving prices up dramatically despite what remains a very elastic supply of land. As a result, prices accelerated and building increased faster than immigration and household formation could absorb the new inventory.

Another important aspect of housing market efficiency is that prices tend to be sticky downward. In most markets, when excess supply develops, prices fall quickly to clear the market. But housing downturns have been characterized by sticky prices. Sales and starts drop but prices are slow to respond.

Demand can drop for a variety of reasons: demographic pressures, a weak core economy with falling income or rising unemployment, home prices simply rising far faster than income, or a change in market psychology. On the other hand, there have been clear instances of overbuilding, where supply simply grew faster than demand. All these causal factors can be present in a single market, and they always interact. A decline in a regional economy or a glut of condominiums can drive up the number of listings, newspaper articles, and for-sale signs, which can trigger a shift in consumer psychology that may accelerate the demand decline.

Prices might be slow to respond to imbalances for various reasons. Since housing is heterogeneous, comparable sales do not represent identical units,

7. Case and Shiller (1987, 1989).

8. On the former period see Case and Shiller $(1988,1990)$.

9. Glaeser (2002); Glaeser and Gyourko (2002); Glaeser, Gyourko, and Saks (2005, 2006); Glaeser, Gyourko, and Saiz (2009). 
so sellers are uncertain of the actual worth of their property. Value is determined in a stochastic process in which buyers and sellers search for terms that will lead to a sale. Also, sellers tend to view the worth of their property as embodied in comparable sales at the peak.

The dramatic rise in inventory of unsold homes at the beginning of every downturn is strong evidence of this stickiness. Responses to the survey questions discussed above also provide direct evidence. Buyers who had sold properties before buying in the four metropolitan areas surveyed (Boston, Orange County, San Francisco, and Milwaukee) were asked, "If you had been unable to sell your home for the price that you received, what would you have done?" Of the 254 respondents to the first survey in 1988, 95 (37 percent) said that they would have "left the price the same and waited for a buyer, knowing full well that it might take a long time." Another 70 respondents ( 28 percent) answered that they would have taken the house off the market or rented it, and 77 (30 percent) answered that they would have "lowered the price step by step hoping to find a buyer." Only 12 respondents ( 5 percent) answered that they would have "lowered the price until a buyer was found." Results tabulated for the spring 2008 version of the same survey show that individual sellers are more likely to reduce the price when demand drops. But even in this survey only 20 percent said they "would have lowered the price until they found a buyer."

Downward stickiness has been most evident when demand declines are triggered by mortgage rate increases and most homeowners are sitting on fixed-rate mortgages. The classic example occurred at the end of the California boom from 1975 to 1980 . Home prices during that boom increased 147 percent. But in 1981 interest rates rose and the average mortgage rate settled between 16 and 18 percent. The combination of high interest rates and the recession caused the housing market to cool sharply, yet prices in California never fell in nominal terms during the ensuing period. Selling induced the enforcement of due-on-sale clauses, and with interest rates so high, potential sellers preferred to hold onto their low fixed-rate mortgages. Interestingly, Vancouver, Canada, experienced a very similar run-up in the late 1970s. However, Canadian law prohibits fixed-rate mortgages with terms exceeding 10 years. As a result, the increased rates led to higher payments, which homeowners could not afford. Many sold out or went into foreclosure. The average nominal price fell by about 60 percent. ${ }^{10}$

10. Repeat sales indexes for Canada were provided by Stanley Hamilton, University of British Columbia. 
When demand declines and prices stick, agreements are still reached and properties do sell. Buyers with enough income or wealth can participate in the market and may strongly prefer specific units. Despite the market turmoil in late 2008, existing-home sales reported by the National Association of Realtors remained at a seasonally adjusted rate of 4.98 million as of October. Foreclosure sales reported by Realtytrac accounted for about 1.0 million, or 20 percent, of these sales.

The S\&P/Case-Shiller indexes are based on essentially all arm's-length sales of property, but many observed sales are foreclosure sales. Although the indexes exclude bank purchases, which are usually made at the mortgage amount, they include bank sales. When a bank or other institution holding a property after a foreclosure puts the home on the market, its goal is to clear inventory. Hence there is little observed stickiness. In addition, most foreclosed properties in the recent episode were financed with variable-rate rather than fixed-rate mortgages, and the downturn in home prices was not triggered by a rate spike.

Some argue that the Case-Shiller indexes are biased in that auction sales at fire-sale prices do not represent the "real" market. Any metropolitanarea price index is, of course, subject to aggregation bias, because each metropolitan area is made up of many submarkets. A clearer picture of price movements across space requires submarket indexes, which are available (see table 6 below).

Many properties sold at auction had originally been purchased at the peak of the market. Lower-tier price indexes in the glut markets of Las Vegas, Los Angeles, Miami, Phoenix, and San Diego more than doubled (in some cases tripled) between 2000 and 2006. Excluding auction sales of the properties that inflated dramatically during the boom would present a biased view of where the market ultimately settled after the bust.

\section{Housing Markets Have Traditionally Been Quantity Clearing Markets}

Downwardly sticky prices lead to "quantity clearing markets" rather than "price clearing markets." In most markets with excess supply, prices and output fall immediately. If prices are slow to respond, however, the burden of adjustment falls on the quantity of production, prolonging the cycle.

Home prices have followed exactly that pattern over many years. Demand drops. The inventory of unsold homes rises. Prices stick. Output falls. The inventory of unsold property remains high (because a house is a durable good, not a consumable). But household formation rates remain positive, and the new households eventually absorb the excess inventory 
Figure 7. Housing Starts, Monthly Data, 1972-2008

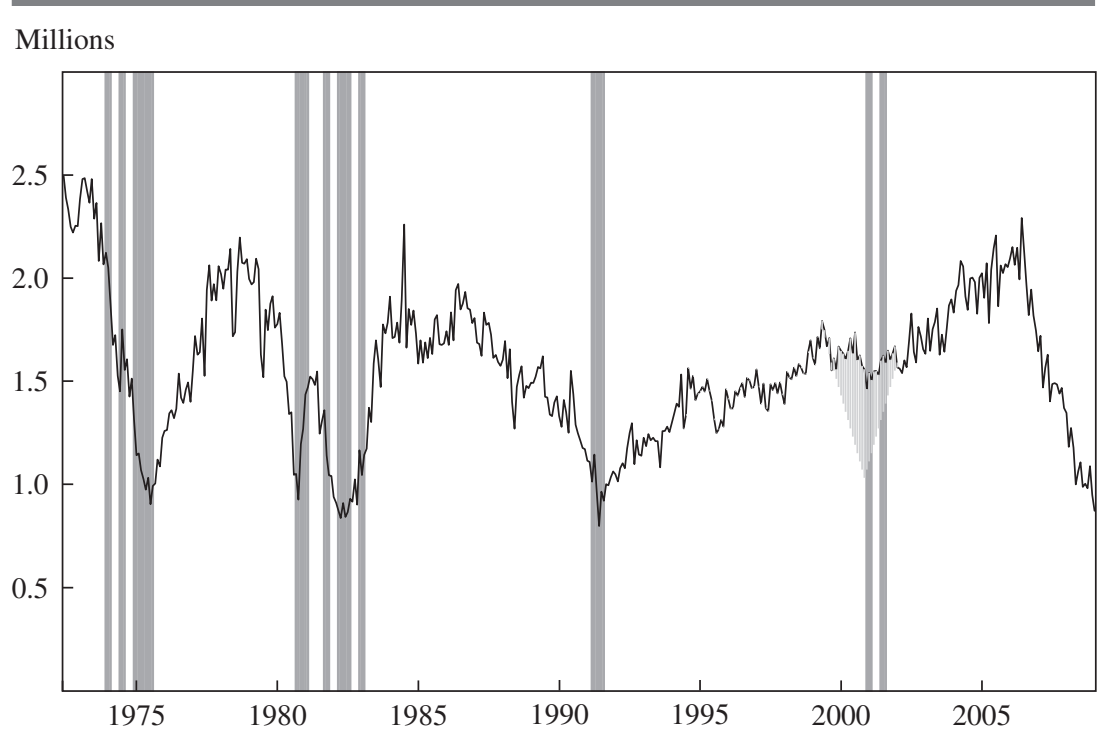

Source: U.S. Census Bureau.

a. Vertical bands indicate quarters of negative GDP growth. Shading indicates the decline in starts that would have been expected given the decline in economic activity in that period.

and output rebounds. Assuming there is upward inertia, prices then rise and ultimately overshoot; demand again slows, starting the next cycle.

The process is accelerated by the fact that housing production is a large part of aggregate demand. When production falls off, it slows the economy, which slows demand growth. John Quigley and I found large income effects from the contractions in housing production that the United States has experienced over the years. ${ }^{11}$

Figure 7 shows just how regular the cycle has been. Since the early 1970s, the United States has gone through four major housing cycles, with peaks in 1972, 1978, 1984, and 2006. Each time housing starts rose above 2 million on an annualized basis, the cycle turned. In the first three cycles, starts then fell by more than 60 percent, to less than a million, before turning up again. In the current cycle, starts hit exactly a million in December 2007 and then bounced up and down for a few months. October 2008, the most recent month for which data are available, was the slowest to date in this cycle, with 625,000 starts.

Table 4 further illustrates the amazing regularity of the cycle in the past. The top of every cycle finds real gross residential investment at about

11. Case and Quigley (2008). 
Table 4. Gross Residential Investment and Housing Starts in Down Cycles, 1973-2008

\begin{tabular}{lccc} 
Cycle & Peak & Trough & $\begin{array}{c}\text { Change } \\
\text { (percent) }\end{array}$ \\
\hline $1973-75$ & & & \\
Gross residential investment & $1973 \mathrm{Q} 1$ & $1975 \mathrm{Q} 1$ & -40 \\
Billions of 2000 dollars & $\$ 308.3$ & $\$ 186.1$ & \\
As percent of GDP & 7.2 & 4.4 & -64 \\
Housing starts & January 1973 & February 1975 & \\
Millions of units & 2.481 & 0.904 & -45 \\
1978-82 & & & \\
Gross residential investment & $1978 \mathrm{Q} 3$ & $1982 \mathrm{Q} 3$ & -61 \\
Billions of 2000 dollars & $\$ 321.5$ & $\$ 175.6$ & \\
As percent of GDP & 6.3 & 3.4 & \\
Housing starts & December 1977 & November 1981 & -24 \\
Millions of units & 2.142 & 0.837 & \\
1984-91 & & & \\
Gross residential investment & $1986 \mathrm{Q} 3$ & $1991 \mathrm{Q} 1$ & -65 \\
Billions of 2000 dollars & $\$ 341.3$ & $\$ 258.6$ & \\
As percent of GDP & 5.4 & 3.7 & \\
Housing starts & February 1984 & January 1991 & \\
Millions of units & 2.260 & 0.798 & -41 \\
2005-08 & & & \\
Gross residential investment & $2005 \mathrm{Q} 4$ & $2008 \mathrm{Q} 3$ & \\
Billions of 2000 dollars & $\$ 602.0$ & $\$ 353.7$ & \\
As percent of GDP & 5.4 & 3.0 & \\
Housing starts & January 2006 & November 2008 & \\
Millions of units & 2.273 & 0.625 & \\
\hline Soures Bun of & & & \\
\hline
\end{tabular}

Sources: Bureau of Economic Analysis, Census Bureau construction reports, and Federal Reserve Flow of Funds.

6 percent of real GDP. At the bottom of the last three cycles, the same ratio was on average 3.6 percent of real GDP. The Bureau of Economic Analysis's release of third-quarter GDP in October 2008, however, shows that real gross residential investment has fallen below this historic floor, to 3.0 percent. It shows no sign of rising soon.

Homebuilding is the only major industry that loses 60 percent of its business in a normal contraction. In 2007 the national average cost of a new home was roughly $\$ 300,000$. After subtracting the value of land and imported building materials (based on data from a number of sources, including the National Association of Homebuilders, the Census Bureau's construction reports, and Engineering News Record), each start contributes roughly $\$ 240,000$ in new residential construction to GDP. With starts down to 817,000 (again on an annualized basis), a total of 1.45 million units that would have been built will not be started; their absence represents a demand 
shock of roughly $\$ 348$ billion. This number is confirmed by the reported decline in gross private residential investment from a peak of $\$ 808$ billion in 2006Q1 to $\$ 480$ billion in 2008Q3. Assuming a multiplier of 1.4 , this is equivalent to a drop in aggregate demand of 3.2 percent.

Although past housing cycles have been regular in amplitude, their length has varied. For example, the recovery in housing starts following the recession of 1975 lasted from February 1975 through May 1978, and that following the recession of 1980-81, when housing starts bottomed out at 837,000 in November 1981, reached a new peak of 2.26 million by February 1984. In contrast, the housing expansion that began in the early 1990s was much longer. From a bottom of 798,000 in January 1991, starts took 15 years to climb back to 2.27 million (figure 7).

The data also show that although homebuilding paused in 1999-2000, the housing market "skipped" a cycle. The easy availability of credit that came with the slowdown in 2001 kept the housing market going: building continued to rise through the next slowdown in the economy in 2002-04. The shaded area in figure 7 simulates a typical decline in starts given the mild nature of the recession of 2000-01. Had the homebuilding sector responded typically, 1.2 million fewer housing units would have been built during that period. Census data show that between 2000 and 2004, new housing units exceeded household formations by just fewer than 4 million. With 1.2 million fewer units, the vacancy rate would have been about 30 percent lower in 2004.

\section{Housing Market Performance Depends on Credit Markets and Monetary Policy}

Housing is far more responsive to interest rate changes than any other sector. Historically, when the Federal Reserve has acted to stimulate or slow the economy, housing has shown the greatest first-order response of any sector. The affordability of a given house depends ultimately on the monthly payment, and that depends on the mortgage rate.

From 1970 until 2000, every recession was caused in part by a major rate shock. Between March 1973 and July 1974, the federal funds rate rose from 7 percent to 13 percent. From October 1978 to July 1981, the Federal Reserve pushed the funds rate from 9 percent to almost 20 percent. And from April 1988 to March 1989, it raised the funds rate from below 7 percent to just under 10 percent. In each case the Federal Reserve was responding to inflationary pressure. Similarly, toward the end of each recession, rates came down and helped kick off a housing sector rally. However, the relationship between monetary policy and the housing 
sector was different in a number of ways in the period beginning in 2000, as the next section describes.

\section{The Roots of the Crash}

The 21st century began with an investment-led slowdown and the bursting of the dot-com bubble. After a huge, investment-led expansion, including a 29 percent increase in gross private domestic investment in 2000Q2, investment dropped sharply for six quarters, dragging the economy into negative growth in 2001. The expansion was largely due to expenditure surrounding the $\mathrm{Y} 2 \mathrm{~K}$ problem, which led many firms to replace their entire computer systems. Investment that would have taken place in 2002 and 2003 was effectively shifted to 1999 and 2000.

This period also differed from the beginnings of the three previous recessions in its lack of inflationary pressure. The stock market peaked and began to drop in early 2000, and the tragedies of September 11 created a sense of real crisis late in 2001. In December 2001 the year-over-year change in the CPI was 1.6 percent. Thus, the way was clear for aggressive monetary policy to deal with the recession early, yet gross investment spending was unable to respond to the stimulus of lower interest rates. What responded were the mortgage market and, subsequently, the housing market.

Figure 8 chronicles this period, using data carefully developed by Alan Greenspan and James Kennedy, ${ }^{12}$ who were able to reconcile the differences among the various confusing sources of origination data. Monetary policy began easing in January 2001, when the Federal Reserve cut the funds rate by 50 basis points, from 6.5 percent to 6.0 percent. By the end of the year, the central bank had cut rates 11 times, to 1.75 percent. At the time the easing began, the average 30-year fixed conventional mortgage rate was just below 7.2 percent, down slightly from an average of 8.2 percent for the first nine months of 2000. By the time the federal funds rate hit 1.75 percent in 2000Q4, the conventional fixedrate mortgage was down to 6.8 percent. But rates were just starting their descent. The funds rate continued to decline until June 2003, when it hit 1 percent, by which time the average conventional 30 -year fixed-rate mortgage carried a rate of 5.3 percent. The funds rate then stayed at 1 percent for over a year.

12. Greenspan and Kennedy (2005, 2007). 
Figure 8. Mortgage Originations and the Target Federal Funds Rate, 2000-08

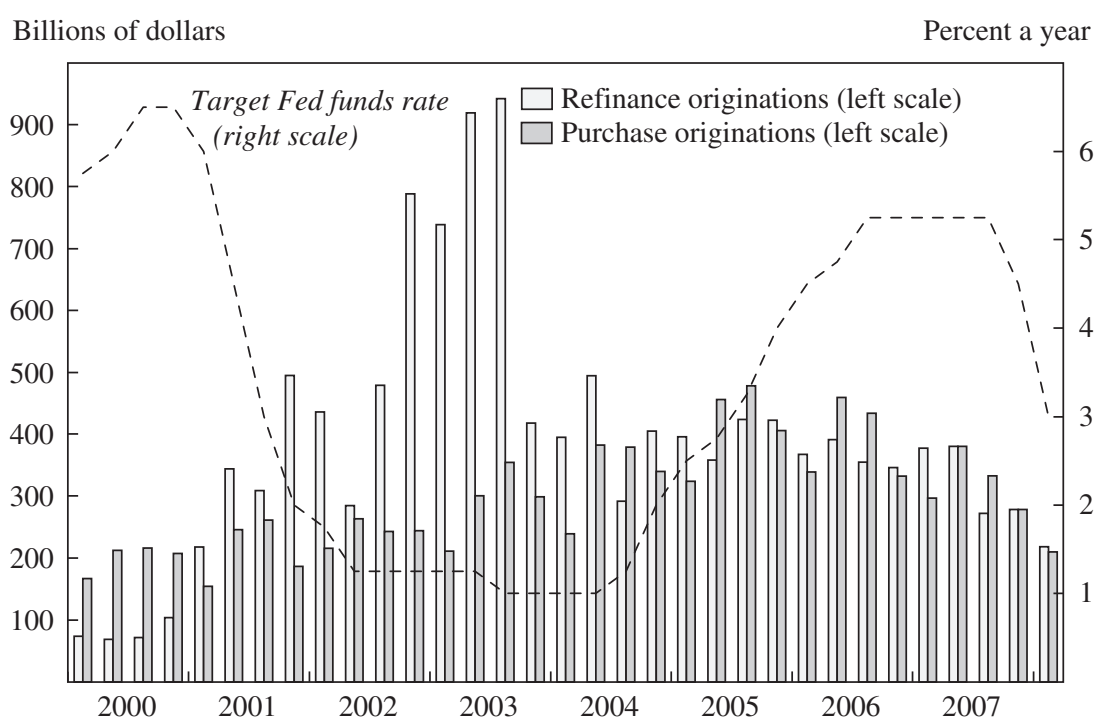

Sources: Greenspan and Kennedy (2005, with updates by James Kennedy); Board of Governors of the Federal Reserve; Standard \& Poor's.

Lower rates made housing much more affordable. At a fixed rate of 8.2 percent, the monthly payment on a $\$ 300,000$ conventional 30 -year mortgage with 20 percent down is $\$ 1,795$ before tax benefits. The monthly payment on the same mortgage with a fixed rate of 6.8 percent is $\$ 1,565$, and with a 5.3 percent rate it is $\$ 1,333$. Thus, expansionary policy cut the cost of buying a home by almost a third.

The sharply lower rates had a powerful effect on the mortgage and housing markets. The housing market kept the economy out of recession and helped it grow substantially through the turbulent early and mid-2000s. Figure 8 shows that the volume of mortgage lending exploded at the end of 2002, beginning with a huge refinancing boom. Between 2002Q4 and 2003Q4, \$5.5 trillion in mortgages was originated and \$3.7 trillion was paid off. Over five quarters the market's total originations were about the same as the total stock of mortgage debt outstanding in 2001. Seventy-five percent of originations were refinancings.

In June 2003 mortgage rates spiked and began to rise, jumping from 5.3 percent to 6.3 percent by August. The third quarter of 2003 saw the highest-ever volume of refinancings, with originations of $\$ 942$ billion, as 
borrowers scrambled to catch the bottom. After that the "refi" boom was over: in 2003Q4 refinancings fell by 56 percent.

During the expansion of credit up to the end of 2003, the mortgage industry grew and became highly competitive. With fee income averaging about 2.5 percent on each transaction, the sector earned over $\$ 100$ billion on total originations of $\$ 4$ trillion in 2003. In addition, the book of business had very low default rates.

Armed with huge books of profitable business, booming home prices, very low default and foreclosure rates, and general prosperity, along with the federal government's continued push for the American dream of homeownership, lenders competed for homebuyers' business. Purchase originations doubled from $\$ 239$ billion in 2004Q1 to \$478 billion in 2005Q3. Much of the business was directed at low-cost neighborhoods and subprime borrowers. In all, between 2002Q4 and 2006Q4, the market originated a staggering \$14.4 trillion in mortgage paper, paid off $\$ 10.3$ trillion, and pushed the value of total one-to-four-family residential mortgage liabilities from $\$ 6.2$ trillion to $\$ 10.3$ trillion, according to the Greenspan-Kennedy data. Table 5 uses data collected by the Federal Financial Institutions Examination Council under the Home Mortgage Disclosure Act to show how lending shifted into low- and moderate-income tracts in virtually every metropolitan area.

Credit expansion of this magnitude had a major impact on the housing market. Prices rose across the board. As shown in table 2, between 2000 and 2006 bottom-tier prices increased the most, by 241 percent in Miami, 240 percent in Los Angeles, and just under 200 percent in Washington, D.C., and San Diego. The S\&P/Case-Shiller Composite 10 and Composite 20 indexes more than doubled, and the national index was up nearly 90 percent.

Finally, at the end of 2005 and into 2006, the housing market began to soften for a variety of reasons. Interest rates rose, as Federal Reserve tightening pushed the federal funds rate back up to 5.4 percent and the 30-year mortgage rate followed to 6.6 percent by the second half of 2006. Gluts of speculative building occurred in Arizona, Florida, and Nevada. Housing in California and the Northeast became very expensive relative to incomes. The manufacturing base of the Midwest fell into recession. As expectations turned gloomy, 16 of the 20 Case-Shiller metro areas saw prices falling in 2005 or 2006. By 2007 all 20 were falling.

Inventories of housing rose. In the past, when markets had overshot, prices were sticky and adjustment was orderly. But with home prices falling nationally, and with virtually all of the current mortgage debt having been 
Table 5. Originations in Low- and Moderate-Income Census Tracts by Metropolitan Area, 1999-2006

Percent of total purchase loans

\begin{tabular}{|c|c|c|c|c|c|c|c|c|c|}
\hline \multirow[b]{2}{*}{ Metropolitan area ${ }^{\mathrm{a}}$} & \multirow[b]{2}{*}{1999} & \multirow[b]{2}{*}{2000} & \multirow[b]{2}{*}{2001} & \multirow[b]{2}{*}{2002} & \multirow[b]{2}{*}{2004} & \multirow[b]{2}{*}{2005} & \multirow[b]{2}{*}{2006} & \multicolumn{2}{|c|}{$\begin{array}{c}\text { Price change } \\
\text { (percent), } \\
\text { lower tier }\end{array}$} \\
\hline & & & & & & & & $\begin{array}{c}2000- \\
\text { peak }\end{array}$ & $\begin{array}{c}\text { Peak to } \\
\text { October } \\
2008\end{array}$ \\
\hline Detroit & 10 & 11 & 12 & 13 & 25 & 28 & 30 & & $\ldots$ \\
\hline Boston & 17 & 18 & 18 & 19 & 26 & 29 & 30 & 119 & -21 \\
\hline Miami & 14 & 14 & 13 & 14 & 21 & 24 & 27 & 241 & -46 \\
\hline Phoenix & 13 & 14 & 13 & 15 & 20 & 24 & 26 & 139 & -48 \\
\hline Los Angeles & 11 & 13 & 13 & 16 & 23 & 24 & 25 & 240 & -46 \\
\hline Chicago & 9 & 14 & 14 & 16 & 20 & 22 & 23 & 84 & -18 \\
\hline New York & 9 & 9 & 10 & 12 & 18 & 21 & 23 & 160 & -14 \\
\hline San Francisco & 17 & 17 & 17 & 17 & 20 & 23 & 23 & 176 & -58 \\
\hline San Diego & 13 & 13 & 14 & 15 & 21 & 22 & 23 & 197 & -46 \\
\hline Washington, D.C. & 13 & 13 & 14 & 16 & 19 & 21 & 23 & 197 & -36 \\
\hline Tampa & 15 & 15 & 14 & 15 & 18 & 21 & 23 & 180 & -34 \\
\hline Portland, Ore. & 12 & 12 & 11 & 12 & 18 & 20 & 21 & 100 & -9 \\
\hline Atlanta & 12 & 13 & 13 & 14 & 18 & 20 & 21 & 38 & -17 \\
\hline Seattle & 12 & 12 & 12 & 13 & 18 & 19 & 20 & 102 & -13 \\
\hline Denver & 18 & 17 & 16 & 16 & 19 & 20 & 20 & 39 & -15 \\
\hline Minneapolis & 10 & 10 & 11 & 12 & 16 & 18 & 18 & 88 & -26 \\
\hline Cleveland & 15 & 14 & 13 & 13 & 16 & 18 & 17 & 33 & -27 \\
\hline Dallas & 12 & 11 & 10 & 10 & 12 & 13 & 13 & $\ldots$ & $\ldots$ \\
\hline Charlotte & 9 & 9 & 9 & 9 & 12 & 11 & 12 & $\ldots$ & $\ldots$ \\
\hline Las Vegas & 5 & 4 & 4 & 4 & 10 & 11 & 11 & 144 & -45 \\
\hline United States & 12 & 12 & 12 & 12 & 16 & 18 & 18 & & \\
\hline
\end{tabular}

Source: Federal Financial Institutions Examination Council, Standard \& Poor's, and author's calculations. a. Metropolitan areas are ordered by their 2006 values.

written since 2004, the bulk of it at high loan-to-value ratios, the default rate rose sharply.

Meanwhile underwriting practices had changed. Over the past 30 years, default and foreclosure models had been developed that seemed to "explain" differences in default and claim incidence as a function of borrower and loan characteristics. All market participants used these models, sometimes without even knowing it. Fannie Mae and Freddie Mac wrote the code for their ironically named automated underwriting systems, "Desktop Underwriter" (now sometimes called "Desktop Undertaker") and "Loan Prospector," by running thousands of regressions, which reported high explanatory power. Their specific purpose was to accurately price the risk that originators and secondary market participants were taking. Their low 
Figure 9. Home Prices and Underwriting Credit Risk

Home prices

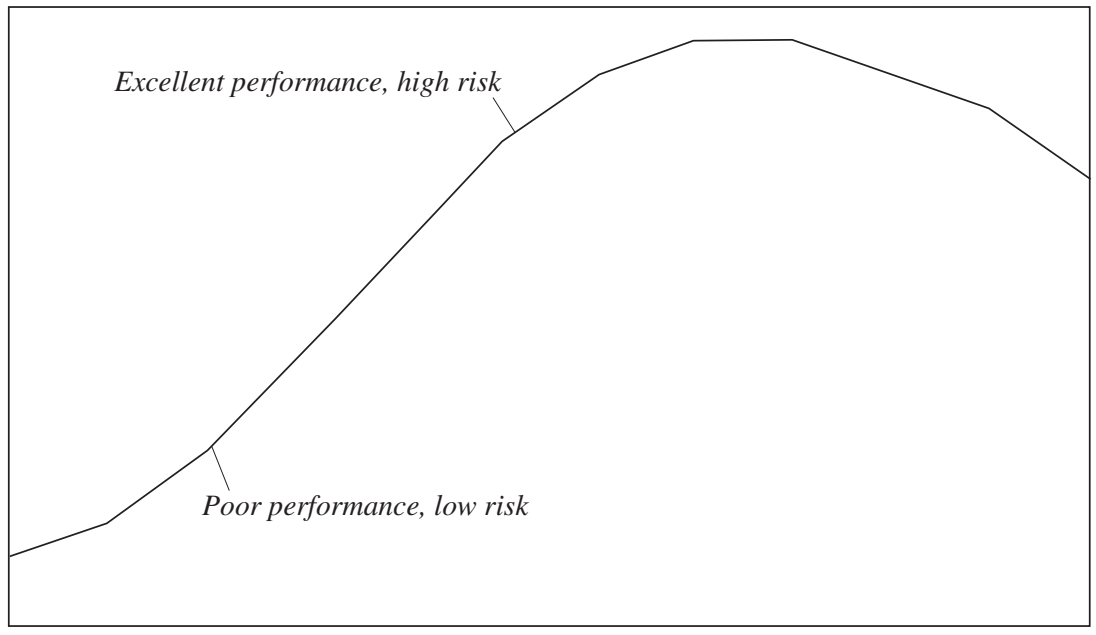

Time

cost and ease of operation made them the industry standard, and originators and mortgage insurance companies that would not accept their decisions received no business.

The stated goal was to transform the current patchwork risk allocation process into a more efficient and accurate risk-based pricing system. The problem was that the regressions on which the automated systems were based had been run with data from a 30-year period of continuously rising national home prices, where regional price declines coincided with regional economic performance. Thus, the model concluded that as long as a portfolio was regionally diversified and pricing was based on credit scores, loan-to-value ratios, and so forth, the business would be profitable. When instead home prices declined everywhere and the regional cycles became more synchronized, the model no longer fit the data.

Another problem was that the timing of performance-based adjustments to underwriting standards was subject to the "fool in the shower" problem. Consider a city that experiences the time path of home values shown in figure 9. The timing of the turns is unknown ex ante. The optimal time to apply the brakes on writing risk is precisely when prices are rising. Paper written at the peak is the most vulnerable, but at that moment default rates are at a minimum. In the current downturn, the disastrous 2005 and 2006 
books of business were written while the mortgage industry was enjoying excellent results with few defaults.

\section{What Are the Indexes Telling Us Now?}

The years between 2000 and 2005 witnessed a boom of historical proportions, as described in detail above. That boom enjoyed credit market underpinning unlike any other in history. Indeed, the period from 2000 to 2008 is among the truly important economic episodes of the last century. Today all eyes are still focused on home prices, to see what will happen next. How fast and how far will prices fall? And when will some sense of equilibrium be restored?

To a very large extent, the media, the regulators, and the public are all relying on the various indexes, including the S\&P/Case-Shiller indexes, that are reported each month and, in at least one instance, each day. Some regulators and accounting firms are using the indexes on a metropolitanarea basis to value portfolios of distressed housing-backed assets. The indexes are meant to measure changes in the "market value" of housing, essentially single-family houses, in a given area. From a legal perspective, the market price for a property is what a willing buyer would agree to pay a willing seller in an arm's-length exchange, which implies that in calculating an index point, every available arm's-length sale should be considered. If this market were pricing a relatively homogeneous good, measuring price movements would be simple. But in the housing market today, two kinds of prices are being generated from two fundamentally different equilibrium processes. These two processes operate side by side, often neighborhood by neighborhood, within metropolitan areas.

The first is the traditional search process involving would-be homebuyers and individual homeowners wishing to sell; this process is characterized by downwardly sticky prices, high inventory, and aversion to loss on the part of sellers. Liquidity-constrained sellers are actually more reluctant to sell than unconstrained sellers, because selling may have high transactions costs. Evidence also suggests that homeowners do not like to sell at a loss. This type of market clearing is slow, usually resulting in an extended and costly period of quantity adjustment with relatively little price change. Second, and concurrently, banks, servicers, and other players are left holding portfolios of houses acquired through default and foreclosure. These properties are typically auctioned off to the highest bidder, often at very low prices.

The parallel operation of these two processes is not a new phenomenon. In every past regional decline, both processes worked together to clear the 
Table 6. Changes in Home Prices in Massachusetts, Second Quarter 2008

\begin{tabular}{lcccc}
\hline & \multicolumn{3}{c}{ Percent change } & Median price \\
City or town & One year & Five years & Ten years & (dollars) \\
\hline Brockton & -14.85 & +6.53 & +137.06 & 230,000 \\
Lawrence & -13.02 & +14.01 & +167.94 & 165,000 \\
Worcester & -11.28 & +6.76 & +101.64 & 230,000 \\
Lynn & -10.47 & +5.40 & +109.33 & 250,500 \\
North Dartmouth & -10.15 & +13.72 & +123.90 & 258,000 \\
Northborough & -9.09 & +5.02 & +83.97 & 372,000 \\
North Andover & -7.48 & +2.81 & +77.53 & 500,000 \\
Westborough & -6.43 & +7.19 & +82.55 & 350,000 \\
Andover & -5.55 & +3.63 & +81.47 & 519,000 \\
Lynnfield & -5.22 & +10.45 & +103.29 & 494,000 \\
Southborough & -5.20 & +9.75 & +88.92 & 533,000 \\
Springfield & -5.15 & +46.53 & +125.77 & 159,000 \\
Weymouth & -5.00 & +10.53 & +127.50 & 285,000 \\
Gloucester & -4.45 & +8.31 & +105.27 & 385,000 \\
North Adams & -3.82 & +40.14 & +101.58 & 127,000 \\
Walpole & -2.66 & +11.68 & +98.75 & 402,500 \\
Billerica & -2.51 & +9.87 & +94.99 & 326,000 \\
Weston & -0.94 & +13.62 & +95.45 & $1,202,500$ \\
Lexington & -0.45 & +11.70 & +98.29 & 839,000 \\
Wellesley Hills & -0.29 & +16.73 & +101.76 & $1,210,000$ \\
Lincoln & -0.22 & +12.03 & +99.14 & $1,045,000$ \\
Dover & +0.21 & +17.50 & +105.37 & 932,500 \\
Needham & +0.64 & +16.10 & +103.57 & 716,500 \\
Belmont & +0.68 & +17.21 & +108.87 & 722,500 \\
Waltham & +1.03 & +16.26 & +109.30 & 389,000 \\
Newton & +2.74 & +19.93 & +110.01 & 895,500 \\
Cambridge & +12.63 & +40.75 & +166.84 & 590,000 \\
\hline Souce: Fis & & &
\end{tabular}

Source: Fiserv CSW.

market. In the New England decline of 1989-90, average single-family home prices were down roughly 11 percent, yet the glutted condominium markets had concentrations of ill-advised conversions that lost 75 percent of their original value when sold at auction. ${ }^{13}$ Table 6 presents average sale prices for a nonrandom sample of zip codes in Massachusetts through 2008Q2, showing that prices in the areas of low and moderate income-price ratios are down significantly more than in areas with higher ratios. Evidence suggests that foreclosed properties in most cities trade at significantly larger losses than properties not in foreclosure. Fiserv CSW has calculated preliminary repeat sales indexes on cities with large quantities of foreclosed

13. Case (1991). 
Figure 10. S\&P/Case-Shiller Home Price Index for Miami, 1972-2008

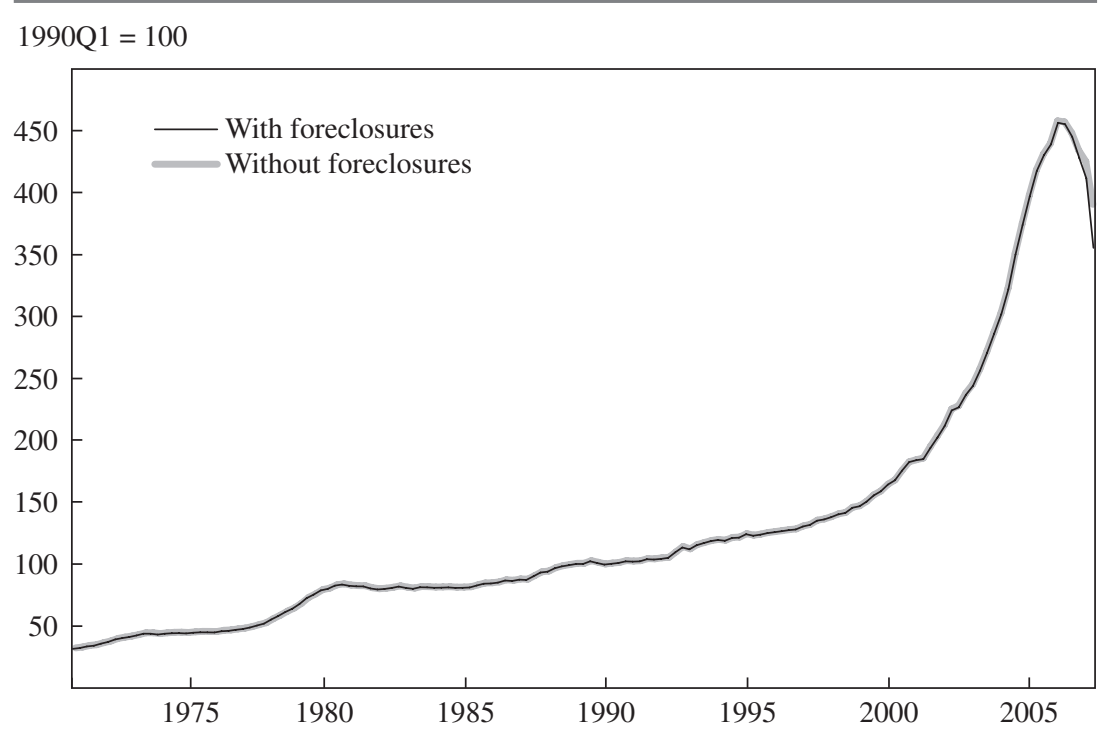

Source: Fiserv CSW.

properties both with and without the foreclosure sales in the data. In Miami as of 2008Q1, the index with the full sample showed a 22 percent decline since the peak of prices, whereas the index excluding auction sales showed only a 15 percent decline (figure 10). In Chicago the comparable figures are 10 percent and 7 percent. The difference is greater for Cleveland.

There are three potential explanations for these differences. First, the foreclosed properties are typically, although not exclusively, in neighborhoods in the lower tier that had experienced rapid run-ups and very high peaks in 2006 and 2007 (see table 2). Second, auction sales typically involve less "price discovery" and search. Although not all such sales are fire sales, most firms that hold foreclosed property prefer to move it off their balance sheets quickly. Third, many foreclosure properties are not properly maintained during the foreclosure process; thus, some substantial unobserved quality change can occur. The indexes have some remedies for these problems.

In using the indexes to value the stock of housing, it is important to understand that all are based on transactions. To the extent that these transactions do not represent the stock, the indexes may be a biased estimator of changes in the stock's value. The only way to deal with this problem is to 
Table 7. Value of Owner-Occupied Housing in Selected States, Fourth Quarter 2005

\begin{tabular}{lcc} 
State & Billions of dollars & $\begin{array}{c}\text { Percent of total U.S. } \\
\text { housing value }\end{array}$ \\
\hline United States & 18,336 & 100.0 \\
California & 4,554 & 24.8 \\
Florida & 1,389 & 7.6 \\
New York & 1,382 & 7.5 \\
Connecticut & 898 & 4.9 \\
New Jersey & 881 & 4.8 \\
Illinois & 762 & 4.2 \\
Texas & 715 & 3.9 \\
Massachusetts & 626 & 3.4 \\
Michigan & 495 & 2.7 \\
Washington & 491 & 2.7 \\
Ohio & 478 & 2.6 \\
Arizona & 415 & 2.3 \\
Georgia & 400 & 2.2 \\
North Carolina & 373 & 2.0 \\
Minnesota & 330 & 1.8 \\
Colorado & 318 & 1.7 \\
Oregon & 255 & 1.4 \\
Nevada & 184 & 1.0 \\
District of Columbia & 55 & 0.3 \\
Above 19 states & & 81.8 \\
\hline Sorce: Cas (2007): & &
\end{tabular}

Source: Case (2007); author's calculations.

carefully explore geographically disaggregated data such as the tier indexes or zip code-level data.

Finally, which states have the biggest problems? Table 7 gives a rough estimate of the value of owner-occupied housing by state. ${ }^{14}$ The biggest area of concern, California, accounts for almost 25 percent of total home value nationwide. Florida and California, which together account for just under a third of the home value in the country, are experiencing the greatest declines in value.

Table 8 reports ratios of foreclosure sales (both "notice of trustee sales" and "notice of foreclosure sales") to total sales of existing homes for 2006Q3 to 2008Q1. (Total sales are from state data; a few states where the data are not consistent are excluded.) For the United States as a whole, this ratio doubled over the period, from 9.3 percent to 18.8 percent. The highest ratios are in Arizona (86 percent), Nevada (62 percent in 2007Q4; this figure fell in 2008Q1), and Georgia (46 percent). California and Florida

14. Case (2007). 
Table 8. Foreclosure Sales as Share of Existing-Home Sales, by State, 2006-08 ${ }^{a}$ Percent

\begin{tabular}{|c|c|c|c|c|c|c|c|}
\hline State & $2006 Q 3$ & $2006 Q 4$ & $2007 Q 1$ & $2007 Q 2$ & $2007 Q 3$ & $2007 Q 4$ & $2008 Q 1$ \\
\hline United States & 9.3 & 9.3 & 11.1 & 12.8 & 18.0 & 18.1 & 18.8 \\
\hline Arizona & 19.6 & 24.4 & 32.8 & 46.1 & 81.0 & 70.0 & 86.3 \\
\hline Nevada & 7.4 & 11.7 & 20.5 & 31.3 & 29.6 & 62.0 & 19.7 \\
\hline Georgia & 19.8 & 25.8 & 29.3 & 29.3 & 39.6 & 45.5 & 45.6 \\
\hline Colorado & 35.3 & 42.7 & 41.2 & 51.1 & 55.8 & 41.9 & 42.0 \\
\hline Michigan & 26.6 & 24.6 & 22.5 & 37.6 & 47.8 & 41.7 & 44.3 \\
\hline California & 4.3 & 6.3 & 10.2 & 19.5 & 30.9 & 39.9 & 32.4 \\
\hline Maryland & 4.4 & 3.7 & 5.8 & 8.9 & 25.5 & 34.2 & 38.6 \\
\hline Utah & 12.6 & 11.5 & 12.4 & 11.2 & 14.6 & 26.1 & 32.3 \\
\hline Ohio & 15.8 & 15.9 & 18.6 & 19.2 & 30.4 & 25.7 & 17.7 \\
\hline Florida & 5.6 & 4.9 & 12.8 & 11.8 & 21.3 & 24.6 & 24.3 \\
\hline Rhode Island & 11.1 & 9.7 & 14.3 & 17.0 & 18.7 & 24.6 & 47.7 \\
\hline Virginia & 3.2 & 2.6 & 4.9 & 8.6 & 21.1 & 20.7 & 33.0 \\
\hline Washington & 10.6 & 11.5 & 14.1 & 14.1 & 16.3 & 19.4 & 20.9 \\
\hline Texas & 24.1 & 20.0 & 21.5 & 13.7 & 23.3 & 19.0 & 18.2 \\
\hline Arkansas & 11.3 & 11.3 & 12.9 & 16.3 & 15.4 & 17.9 & 18.0 \\
\hline Indiana & 13.0 & n.a. & 15.3 & 11.8 & 20.3 & 16.0 & 14.7 \\
\hline Tennessee & 10.0 & 12.3 & 12.3 & 15.2 & 17.2 & 14.5 & 15.8 \\
\hline Missouri & 5.0 & 5.5 & 5.5 & 9.8 & 10.5 & 14.3 & 14.7 \\
\hline Minnesota & 4.4 & 5.9 & 5.9 & 7.7 & 13.5 & 13.5 & 12.0 \\
\hline Nebraska & 7.0 & 8.6 & 8.6 & 5.6 & 8.5 & 12.8 & 7.6 \\
\hline Pennsylvania & 9.2 & 6.5 & 11.2 & 9.8 & 11.7 & 10.7 & 9.4 \\
\hline $\begin{array}{l}\text { Dist. of } \\
\text { Columbia }\end{array}$ & 0.0 & 0.3 & 0.2 & 1.2 & 10 & 10.4 & 48.3 \\
\hline Alaska & 3.1 & 3.4 & 2.9 & 3.6 & 4.8 & 9.5 & 4.5 \\
\hline Idaho & n.a. & n.a. & 8.2 & 7.6 & 12.4 & 9.1 & 19.4 \\
\hline Massachusetts & 8.4 & 5.0 & 6.1 & 12.8 & 16.2 & 8.8 & 27.5 \\
\hline Montana & 3.0 & 4.9 & 4.5 & 4.6 & 4.9 & 6.8 & 7.1 \\
\hline Oregon & 3.4 & 6.7 & 2.6 & 3.3 & 4.2 & 6.1 & 7.8 \\
\hline Illinois & 4.4 & 3.1 & 2.8 & 3.5 & 3.9 & 6.1 & 3.4 \\
\hline Iowa & 0.6 & 3.9 & 5.3 & 3.7 & 7.0 & 5.8 & 5.3 \\
\hline Wisconsin & 2.0 & 2.5 & 2.9 & 3.2 & 5.3 & 5.8 & 7.9 \\
\hline Hawaii & 1.3 & 2.0 & 2.3 & 3.6 & 4.7 & 5.4 & 5.3 \\
\hline New Jersey & 4.4 & 4.6 & 6.0 & 5.5 & 9.3 & 5.2 & 7.8 \\
\hline Alabama & 2.1 & 4.2 & 3.2 & 3.1 & 3.9 & 4.9 & 4.4 \\
\hline Kansas & 3.6 & 4.1 & 4.5 & 4.6 & 4.8 & 4.8 & 4.8 \\
\hline Oklahoma & 5.4 & 4.7 & 6.1 & 4.7 & 6.8 & 4.7 & 5.5 \\
\hline Connecticut & 3.0 & 2.1 & 3.7 & 5.7 & 4.0 & 4.4 & 7.8 \\
\hline Kentucky & 3.1 & 3.1 & 3.8 & 5.0 & 5.3 & 4.3 & 3.8 \\
\hline Maine & 0.8 & 0.7 & 0.5 & 4.7 & 4.2 & 3.6 & 5.7 \\
\hline New York & 5.1 & 4.1 & 2.3 & 2.5 & 3.7 & 2.6 & 3.7 \\
\hline Mississippi & 0.9 & 1.9 & 2.3 & 2.2 & 2.2 & 2.4 & 2.2 \\
\hline West Virginia & 2.3 & 3.1 & 2.8 & 6.3 & 4.0 & 1.7 & 1.6 \\
\hline South Dakota & 1.3 & 1.3 & 1.6 & 1.8 & 1.6 & 1.3 & 1.4 \\
\hline South Carolina & 1.0 & 0.9 & 1.0 & 1.1 & 1.1 & 0.9 & 1.0 \\
\hline Wyoming & 2.1 & 2.4 & 1.0 & 0.5 & 3.7 & 0.9 & 0.3 \\
\hline New Mexico & 1.2 & 1.6 & 1.5 & 0.5 & 0.1 & 0.3 & 0.2 \\
\hline Vermont & 0.1 & 0.1 & 0.0 & 0.3 & 0.3 & 0.3 & 0.2 \\
\hline North Dakota & 0.0 & 0.0 & 0.1 & 0.2 & 0.2 & 0.1 & 0.1 \\
\hline
\end{tabular}

Sources: National Association of Realtors, Existing Home Sales; Realtytrac.

a. States are listed in descending order by values in 2007Q4. Delaware, Louisiana, New Hampshire, and North Carolina are omitted because of data inconsistencies. 
Table 9. Distribution of Foreclosure Auctions by State, 2006-08

\begin{tabular}{|c|c|c|c|c|c|c|c|}
\hline \multirow{2}{*}{$\begin{array}{l}\text { Foreclosure } \\
\text { auctions as } \\
\text { percent of } \\
\text { existing-home } \\
\text { sales }\end{array}$} & \multicolumn{7}{|c|}{ No. of states with indicated share of foreclosure auctions } \\
\hline & $2006 Q 3$ & $2006 Q 4$ & $2007 Q 1$ & $2007 Q 2$ & $2007 Q 3$ & $2007 Q 4$ & $2008 Q 1$ \\
\hline Less than 5 & 27 & 27 & 22 & 21 & 18 & 15 & 14 \\
\hline$\geq 5$ and $<10$ & 9 & 8 & 9 & 10 & 7 & 10 & 11 \\
\hline$\geq 10$ and $<15$ & 5 & 5 & 9 & 7 & 5 & 6 & 3 \\
\hline$\geq 15$ and $<20$ & 3 & 2 & 2 & 5 & 6 & 5 & 7 \\
\hline$\geq 20$ and $<25$ & 1 & 2 & 3 & 0 & 4 & 3 & 2 \\
\hline$\geq 25$ and $<30$ & 1 & 1 & 1 & 1 & 2 & 2 & 1 \\
\hline 30 or greater & 2 & 3 & 2 & 4 & 6 & 7 & 10 \\
\hline
\end{tabular}

Sources: Realtytrac and National Association of Realtors.

have ratios of 32.4 percent and 24.3, percent, respectively. Table 9 shows the shifting distribution of states by the extent of foreclosure sales. Foreclosures are fewer than 5 percent of total existing-home sales in only 14 states today, compared with 27 states in 2006Q3. At the other extreme, only two states had ratios of over 30 percent in 2006 . That figure is now 10 states.

Updates through November 2008 show a substantial drop in total existinghome sales to 4.49 million, at a seasonally adjusted annual rate from a revised 4.91 million in October. Total existing-home sales had been essentially flat at 5 million for a year before the drop in November. Auction sales in November alone totaled 87,700, or about 27 percent of the unadjusted monthly total of 322,000 existing-home sales. California and Florida together accounted for 40 percent of all auction sales in the country in November.

How long will it take for prices to stabilize? The bulk of analysts say it will take a long time. Shiller argues, as does Mark Zandi, that it will take until well into 2010 or longer. ${ }^{15}$ They point to the backlog of unresolved "underwater" mortgages, coming resets of interest rates, large inventories of unsold properties, and the legal delays entailed in unwinding the layers of risk and liabilities built into the new credit instruments. In addition, the crashing stock market and what appears to be a serious recession cast doubt on any overly confident forecast. Add to that uncertainty about the behavior of homebuyers and sellers in a down market nationwide, an environment for which little data are available, and it is no wonder that the futures and 
options markets based on home prices are so illiquid. The real danger is that a continued decline in prices could make the 2008 and 2009 books of mortgages unprofitable, prolonging the credit crunch.

Is there any good news? First, it is clear that the two market clearing processes described above are proceeding in a fairly orderly way. In November 2008 existing-home sales dropped, yet nearly 4.5 million homes (at a seasonally adjusted annual rate) were sold. Although auction sales accounted for 27 percent of the total, that means traditional sales still accounted for 73 percent. In cities like Boston, the current downturn has not been as severe as that of early 1990, from which the market recovered in a remarkably short time.

Second, the battle of the "plans" is under way. Economists and policymakers are focused on settling on a strategy to prevent foreclosures. Preventing foreclosures reduces moving costs, potential vandalism, and the litigation and high transactions costs that often follow foreclosures. In addition, as the number of auctions inevitably declines, traditional sales will gain strength in the home price indexes, and downward resistance will stabilize aggregate prices more quickly.

It is often said that prices will stop rising only when they return to "fundamentals." But what are the fundamentals in housing, and in particular in land? People will bid for locations as long as those with ability to pay are willing to pay for them. Only time will tell when that will be.

ACKNOWLEDGMENTS This paper could not have been written without the help of Rachel Hamilton, Milena Mereva, and Ratha Ly. 


\section{References}

Case, Karl E. 1986. "The Market for Single Family Homes in Boston.” New England Economic Review (May/June): 38-48.

. 1991. "The Real Estate Cycle and the Economy: Consequences of the Massachusetts Boom of 1984-1987." New England Economic Review (Sept./Oct.): 37-46. Revised version in Urban Studies 29, no. 2: 171-83 (Spring 1992).

- 2007. "The Value of Land in the United States: 1975-2005." In Land Policies and Their Outcomes, edited by Gregory K. Ingram and Yu-hung Hong. Cambridge, Mass.: Lincoln Institute of Land Policy.

_. 2009. "What Were They Thinking? The Behavior of Home Buyers in Boom and Post-Boom Markets 1988-2008." Paper presented at the annual meetings of the American Economics Association, San Francisco, January 3.

Case, Karl E., and John M. Quigley. 2008. "How Housing Booms Unwind: Income Effects, Wealth Effects and Feedbacks through Financial Markets." European Journal of Housing Policy 8, no. 2: 161-80.

Case, Karl E., and Robert J. Shiller. 1987. "Prices of Single Family Homes since 1970: New Indexes for Four Cities." New England Economic Review (Sept./Oct.): 45-56.

- 1988. "The Behavior of Home Buyers in Boom and Post-Boom Markets." New England Economic Review (Nov./Dec.): 29-46.

—. 1989. "The Efficiency of the Market for Single-Family Homes." American Economic Review 79, no. 1: 125-37.

1990. "Forecasting Prices and Excess Returns in the Housing Market."

Journal of the American Real Estate and Urban Economics Association 18, no. 3: 253-73.

- 2003. "Is There a Bubble in the Housing Market?" BPEA, no. 2: 299-342.

Congressional Budget Office. 1991. "The Cost of Forbearance during the Thrift Crisis." Staff memorandum. Washington (June).

Davis, Morris, and Jonathan Heathcote. 2005. "Housing and the Business Cycle." International Economic Review 46, no. 3: 751-84.

Davis, Morris, and Michael Palumbo. 2008. "The Price of Residential Land in Large U.S. Cities.” Journal of Urban Economics 63, no. 1: 352-84.

Glaeser, Edward L. 2002. "Comment [on 'Tax Incentives and the City' by Teresa Garcia-Milá and Therese J. McGuire]." Brookings-Wharton Papers on Urban Affairs pp. 115-24.

Glaeser, Edward L., and Joseph E. Gyourko. 2002. “Zoning's Steep Price.” Regulation 25, no. 3: 24-30.

Glaeser, Edward L., Joseph E. Gyourko, and Albert Saiz. 2009. "Housing Supply and Housing Bubbles." Journal of Urban Economics 64, no. 2: 198-217.

Glaeser, Edward L., Joseph E. Gyourko, and Raven E. Saks. 2005. "Why Have Housing Prices Gone Up?" American Economic Review Papers and Proceedings 95, no. 2: 329-33. 
2006. "Urban Growth and Housing Supply." Journal of Economic Geography 6 , no. 1: 71-89.

Greenspan, Alan, and James Kennedy. 2005. "Estimates of Home Mortgage Originations, Repayments, and Debt on One-to-Four Family Residences." Federal Reserve Board Finance and Economic Discussion Series 2005-41. Washington. 2007. "Sources and Uses of Equity Extracted from Homes." Federal Reserve Board Finance and Economic Discussion Series 2007-20. Washington.

Samuelson, Paul. 1957. "Intertemporal Price Equilibrium: A Prologue to the Theory of Speculation." Weltwirtschaftliches Archiv 79, no. 2: 181-221.

Shiller, Robert. 2008. The Subprime Solution: How Today's Global Financial Crisis Happened and What to Do about It. Princeton University Press.

Zandi, Mark. 2009. Financial Shock: A $360^{\circ}$ Look at the Subprime Mortgage Implosion and How to Avoid the Next Financial Crisis. Upper Saddle River, N.J.: FT Press, Pearson Education. 
